\title{
SEROPREVALENCE OF Helicobacter pylori IN PATIENTS WITH COLON ADENOMAS IN A BRAZILIAN UNIVERSITY HOSPITAL
}

\author{
Abadia Gilda BUSO ${ }^{1}$, Haroldo Luis Oliva Gomes ROCHA ${ }^{1}$, Débora Miranda DIOGO², \\ Priscila Miranda DIOGO² and Augusto DIOGO-FILHO ${ }^{3}$
}

\begin{abstract}
Context - The association between Helicobacter pylori infection and colon neoplasia has been the subject of recent investigations which have produced controversial results. Objective - To evaluate the prevalence of H. pylori infection in patients with colonic adenomas and also in patients whose colonoscopy exams were normal. Methods - After colonoscopy, the individuals were distributed into two groups: patients with colon adenomas (cases) and patients whose colons were normal (controls). The groups were similar regarding age and gender. The individuals of both groups were subjected to a dosage of IgG antibody against $H$. pylori. The dosage was applied according to the solid phase, chemiluminescent immunometric assay. The chi-square test was used to analyze the data. Results - There were 30 men and 64 women in each group ( 94 cases and 94 controls). The mean age of the cases was $59.79 \pm 12.25$ years and that of the controls was $58.98 \pm$ 11.55 years. The $H$. pylori serology was positive for 66 (70.21\%) of the cases and for $51(54.25 \%)$ of the controls. There was a significant difference $(P=0.024)$. The odds ratio was 1.98 (CI 95\%, 0.82-3.15). The prevalence of $H$. pylori in cases and controls according to gender, histological type and location of the colon lesions showed a significant difference only among women $(P=0.03)$, among patients with tubular adenomas $(P=0.03)$, and in those with distal adenomas $(P=0.038)$. Conclusion - There is a positive association between $H$. pylori infection and colonic adenomas. This association is more evident in women, especially for tubular adenomas and distal colonic location.
\end{abstract}

HEADINGS - Helicobacter pylori. Adenoma. Colonic neoplasms. Helicobacter infections.

\section{INTRODUCTION}

Helicobacter pylori is a curved or spiral gram-negative polyflagellated bacteria which can colonize the human stomach $^{(21)}$

These bacteria are transmitted orally through interpersonal contact ${ }^{(16,22)}$. A low socioeconomic level and age are the two main risk factors for $H$. pylori infection ${ }^{(27)}$. Its prevalence is high in the populations of developing countries $^{(19,27)}$. In Brazil, epidemiological studies are regional. In adults there are reports of a $66.95 \%$ prevalence in São Paulo ${ }^{(39)}, 64.3 \%$ in Belo Horizonte ${ }^{(27)}$ and more than $80 \%$ in the Northeast and in Mato Grosso, where there is a greater lack of sanitation ${ }^{(29,32)}$. In Uberlândia, $\mathrm{MG}$, there is a verified prevalence of infection in $56.3 \%$ of individuals up to 50 years of age, and $78.8 \%$ in those who are over this age ${ }^{(26)}$.

Individuals infected by $H$. pylori have a chronic inflammation of the stomach mucosa and $10 \%$ to $20 \%$ of them develop a peptic ulcer or gastric neoplasia ${ }^{(14)}$. This is determined by the specific virulence of some strains of the bacteria, as well as by the complex interaction between the host, the environment and the microorganisms ${ }^{(13)}$.
The main pathogenic mechanism of $H$. pylori seems to be the activation of the immunoinflammatory response of the host's gastric cells ${ }^{(12,28)}$, but this stomach infection also helps increase the serum concentration of gastrin ${ }^{(37)}$. Hypergastrinemia has two main effects: an increase in acid secretion by the parietal cells and a hyperproliferation of the mucosal cells of the gastrointestinal tract ${ }^{(17)}$.

The observation that chronic $H$. pylori infection promotes hypergastrinemia and that colon neoplasias also develop with an increase of gastrin serum led several authors to evaluate the possible association between the bacteria and the adenomas and adenocarcinomas of the colon. Epidemiological studies showed a greater prevalence of adenomas and/or adenocarcinomas in patients infected with $H$. pylori $i^{(2,5,10,11,23,24,30)}$.

This association is, however, controversial because other researchers did not identify any association between adenomas and/or colon adenocarcinomas and infection caused by $H$. pylori $(18,25,31,35)$.

In Brazil, there is a lack of studies about the association between H. pylori and colonic polyps.

The purpose of this research was to evaluate the prevalence of $H$. pylori infection in patients with colon 
adenomas and compare it to that of patients whose colonoscopies were normal.

\section{METHODS}

This study was carried out at the "Hospital de Clínicas", Federal University of Uberlândia, MG, Brazil (HC-UFU). It was approved by the Committee of Ethics in Research at the same institution.

During the period from February 2005 to January 2007, all the colonoscopies which were performed by the Endoscopic Digestive Service at the above mentioned hospital were examined. Based on these exams and on their respective biopsies, two groups of adult patients, both male and female, were formed for the type of study known as case-control.

\section{Group 1 - Cases}

Patients with adenomatous polyps of the colon. The identification of polypoid lesions by colonoscopy was followed by polypectomy. The material was conserved in a $10 \%$ formol solution and was then sent to the Pathological Anatomy Laboratory at the HC-UFU, where it was embedded in paraffin, stained with hematoxilin-eosin (H-E) and analyzed by the same group of pathologists using optical microscopy. The histological diagnosis and the classification of the adenomatous polyps were based on the World Health Organization criteria for differentiating tumors ${ }^{(9)}$. The adenomas were classified as tubular, tubulovillous or villous.

Patients with familial polyposis were excluded, as well as those who had already been treated with specific antibiotics for the eradication of $H$. pylori. Also excluded were previous or current patients with abdominal neoplasias.

\section{Group 2 - Controls}

Patients whose colonoscopies were normal. For each case, the control-patient selected was matched to the case-patient; according to gender and age (age within the same decade). Exclusion criteria were the same as those for the cases.

\section{Interviews with the patients}

The patients who fulfilled the inclusion criteria in each group were invited to participate in the research. All were informed about the procedures and signed the terms of clearly informed consent, allowing the exam to be performed.

The individuals were first submitted to a medical interview which included demographic data, use of medicines, and previous history of gastrointestinal and abdominal illnesses.

\section{Serological exams}

After the interview, $5 \mathrm{~mL}$ of venous blood were collected for serological tests. The sample was then sent to the Clinical Laboratory at HC-UFU where it was centrifuged and the serum was submitted to an examination for detection of $\mathrm{IgG}$ antibodies against $H$. pylori. The method employed was the H. pylori solid phase, chemiluminescent immunometric assay with IMMULITE 2000 kits (DPCLab Diagnostic Products Corporation, Los Angeles, CA, USA). Values greater than $1.1 \mathrm{U} / \mathrm{mL}$ were considered positive and those less than $0.9 \mathrm{U} / \mathrm{mL}$ were considered negative. Values between 0.9 and 1.1 were considered inconclusive and the patient was excluded. The serological tests for the identification of $H$. pylori through this method have a sensitivity of $91 \%$ and a specificity of $100 \%^{(36)}$.

\section{Statistical analysis}

The seroprevalence of $H$. pylori in patients with colon adenomas was compared to that of the controls. Gender, histological type of the adenomas and topographical location of the colon lesions were taken into account.

Age was expressed according to measures and standard deviation. For the comparative analysis of the results, the non parametric Pearson chi-square tests in the $2 \times 2$ index were used. In all the tests, the level for the null hypothesis of rejection was set at $5 \%$ or $P<0.05$. The odds ratio was also calculated for the general comparison.

\section{RESULTS}

During the period from February 1st, 2005 to January 31, 2007, 1,862 colonoscopies were performed at the Endoscopy Service of HC-UFU. These colonoscopies showed that 168 patients had adenomatous polyps $(9.02 \%)$ and they were invited to participate in the research study. After subjecting these patients to the inclusion criteria, 94 cases, 30 men and 64 women, were selected for the study. The mean age of these individuals was $59.79 \pm 12.25$ years, ranging from 22 to 84 years. The mean age of men was $59.2 \pm 14.36$ years and of women $60.0 \pm 11.25$ years.

For comparison purposes, 94 control patients, whose colonoscopies were normal, were selected to participate in the study. These patients were matched with the cases according to age (within the same decade). This group was composed of 30 men and 64 women whose mean age was $58.98 \pm 11.55$ years. The ages varied between 24 and 79 years. The mean age of men was $59.1 \pm 12.92$ years and of women was 58.93 \pm 10.95 years.

Serological tests for $H$. pylori were positive in $66(70.21 \%)$ of the cases and in $51(54.25 \%)$ of the controls. This difference was significant $(P=0.024)$. The odds ratio was 1.98 (CI 95\%, $0.82-3.15)$. The evaluation of seroprevalence of $H$. pylori infection in the cases and in the controls when gender was taken into account showed that there was a significant difference for women $(P=0.03)$ and no difference for men $(P=0.417)$ (Table 1$)$.

TABLE 1. Seroprevalence of Helicobacter pylori in patients with colonic adenomas (cases) and in patients with normal colons (controls) according to gender. Colonoscopies performed at the HC-UFU from February 2005 to January 2007

\begin{tabular}{lccc}
\hline Gender & $\begin{array}{c}\text { Cases } \\
+/ \mathbf{n}(\%)\end{array}$ & $\begin{array}{c}\text { Controls } \\
+/ \mathbf{n}(\%)\end{array}$ & $\boldsymbol{P}$ \\
\hline $\begin{array}{l}\text { Men } \\
\text { H. pylori }+ \\
\begin{array}{l}\text { Women } \\
\text { H. pylori }+\end{array}\end{array}$ & $21 / 30(70)$ & $18 / 30(60)$ & 0.41 \\
\hline
\end{tabular}

$+=$ number of patients with positive serology for $H$. pylori $\mathrm{n}=$ total of patients 
Regarding the histology of the adenomatous polyps, $72(76.6 \%)$ were tubular and $22(23.4 \%)$ presented some kind of villous component. A comparison between the seroprevalence of $H$. pylori in patients with tubular adenomas and those of the control group resulted in a significant difference $(P=0.03)$. The comparison between the seroprevalence of the bacteria in patients with villous adenomas and in those of the control group did not show any difference $(P=0.235)$. When the presence of $H$. pylor $i$ was considered for patients with adenomas located in the rectal topography and/or in the sigmoid (distal) or only in the colon (proximal), the prevalence of bacteria was significantly greater in the cases with distal adenomas than in the controls $(P=0.038)$. The prevalence of $H$. pylori in patients with proximal adenomas and in those of the control group did not reach the level of significant difference $(P=0.128)$ (Table 2).

TABLE 2. Seroprevalence of Helicobacter pylori in patients with colonic adenomas (cases) and in patients with normal colons (controls) in accordance with the histological type of the polyps and their location in the colon. Colonoscopies performed at the HC-UFU from February 2005 to January 2007

\begin{tabular}{lccc}
\hline Adenomas (type/location) & $\begin{array}{c}\text { Cases } \\
+/ \mathbf{n}(\%)\end{array}$ & $\begin{array}{c}\text { Controls } \\
+/ \mathbf{n}(\%)\end{array}$ & $\boldsymbol{P}$ \\
\hline Tubular adenomas H. pylori + & $51 / 72(70.83)$ & $51 / 94(54.25)$ & 0.030 \\
Villous adenomas H. pylori + & $15 / 22(68.18)$ & $51 / 94(54.25)$ & 0.235 \\
Distal adenomas H. pylori + & $38 / 53(71.69)$ & $51 / 94(54.25)$ & 0.038 \\
Proximal adenomas H. pylori + & $28 / 41(68.29)$ & $51 / 94(54.25)$ & 0.128 \\
\hline
\end{tabular}

$+=$ number of patients with positive serology for $H$. pylori

$\mathrm{n}=$ total of patients

\section{DISCUSSION}

This study showed that in our region patients with colon adenomas present a greater prevalence of $H$. pylori infection than those with normal colons. These findings are in accordance with those of some other studies in which a similar methodology was used. Some of these studies found a greater prevalence of the bacteria in patients with colon adenomas or adenocarcinomas than in those of the control group ${ }^{(1,2,5,6,10,11,23,24,30)}$. However, different results from those of our study and of the above studies were also reported. Some authors described a similar prevalence of $H$. pylori in patients with colon neoplasias and in the controls who did not have colonic disease ${ }^{(7,18,25,31,35)}$. In a meta-analysis published in 2006, studies of the association between $H$. pylori infection and the risk of colorectal cancer were evaluated and an odds ratio of 1.4 was found ${ }^{(40)}$. The odds ratio calculated in this study was 1.98 and this suggested that $H$. pylori could be a risk factor for the occurrence of adenomatous polyps in the colon.

There are two possible physiopathological explanations for the probable association between $H$. pylori infection and adenomas and adenocarcinomas of the colon: a direct action of the bacteria on the colonic mucosa producing a direct carcinogenic effect and an indirect action of $H$. pylori through hypergastrinemia producing a trophic effect for the mucosal cells of the colon ${ }^{(33)}$.
The passage of $H$. pylori through the colon and its elimination in the human feces is already a well-known fact, since the bacteria could be cultivated by the fecal material of the infected patients ${ }^{(34)}$. Some studies were able to identify the genetic material of the bacteria in colonic neoplasias ${ }^{(3,8,15)}$. The effect of the intestinal flora as a carcinogenic agent has been evaluated and the possibility exists that bacteria such as H. pylori circulating in the intestines could directly activate carcinogenesis ${ }^{(33)}$. Another possibility is that the reduction in the gastric acid provoked by the chronic gastritis caused by $H$. pylori could alter the normal gastrointestinal flora and this modification could be associated with the promotion of carcinogenesis $^{(38)}$.

A second mechanism, the hormonal one, probably explains the association between $H$. pylori and colon neoplasias. The colonization of the gastric mucosa by bacteria activates the production of proinflammatory cytokines which are chemotactic for the neutrophils and lymphocytes that infiltrate into the gastric mucosa and generate chronic gastritis. Another role for these proinflammatory substances is the stimulation of the $G$ cells that provoke hypergastrinemia. The gastrin induces hyper proliferation of the colonic mucosa. It is a known fact that the main event in colonic carcinogenesis is the accumulation of genetic epithelial mutations. The increased number of cellular mitoses could augment mutations ${ }^{(17)}$. Besides the increase in serum gastrin, an increase in the number of its receptors in the neoplastic tissue of the colon was also described ${ }^{(17)}$. Hypergastrinemia and inflammatory cytokines also induce an increase in cyclooxygenase 2 (COX2) which catalyses the formation of prostaglandin E2 (PGE2). This in turn increases angiogenesis in neoplastic tissue, reduces apoptosis and increases cellular proliferation and mutagenesis ${ }^{(17)}$.

The association between $H$. pylori infection and colon adenomas was analyzed in this study for both men and women but a difference was found only for the women. The number of male patients was small so it might not have been sufficient to calculate a significant difference.

On the other hand, the greatest risk for colonic adenomas in women is associated with hormonal factors ${ }^{(6)}$. The mean age of the female patients examined in this study was over 50 years, so they probably had reduced levels of sex hormones. Estrogen and progesterone reduce the risk of adenomas and of adenocarcinomas in the colon. A possible interaction between $H$. pylori and low levels of female sex hormones was described in the development of colonic neoplasias in women ${ }^{(6)}$.

When the cases in our study were evaluated in accordance with the histological type of the adenomas, the data showed that $H$. pylori infection was significantly prevalent only in individuals with tubular adenomas. Here too, the number of patients in each group could have influenced the result. The group of patients with tubular adenomas was greater than that of the patients with villous adenomas. There was also a greater seroprevalence of $H$. pylori in the group with villous adenomas than in the control group, however, the number of patients could have been too small a basis for the definition of a significant difference. The physiopathology and risk factors of the tubular and villous adenomas are the same ${ }^{(4)}$. 
In an epidemiological study about the prevalence of $H$. pylori in patients having different histological types of adenomas, no difference was found in the seroprevalence of the bacteria in distinct histological types of adenomatous polyps ${ }^{(1)}$.

In the evaluation performed in this study, there was a greater seroprevalence of $\mathrm{H}$. pylori infection both in patients with proximal and distal adenomas. However, a significant difference was found only in the cases with distal lesions. An experimental study with laboratory animals described that gastrin promoted cellular proliferation only in distal colonic neoplasias ${ }^{(20)}$. Another study, which was in agreement with the above, observed higher serum levels of gastrin in patients with rectal tumors than in those with proximal colon tumors ${ }^{(35)}$.

\section{CONCLUSION}

As was described above, date presented in this study show that $H$. pylori infection could be a risk factor in the occurrence of colonic adenomas. The association between $H$. pylori infection and colon adenomas was more evident in women, especially regarding tubular adenomas and distal colonic lesions. Because this study is epidemiologic, it is not possible to establish consistently that there is a cause and effect relationship between colonic adenomatous polyps and infection caused by the bacteria involved. Multicentric epidemiologic evaluations and basic physiopathological research might be able to make this association clearer in the future.

Buso AG, Rocha HLOG, Diogo DM, Diogo PM, Diogo-Filho A. Soroprevalência de Helicobacter pylori em pacientes com adenomas de cólon em um hospital brasileiro. Arq Gastroenterol. 2009;46(2):97-101.

RESUMO - Contexto - A associação entre a infecção pelo Helicobacter pylori e as neoplasias de cólon tem motivado alguns estudos recentes, porém os resultados ainda são controversos. Objetivo - Avaliar a prevalência da infecção pelo H. pylori em pacientes com adenomas colônicos e naqueles com cólons normais à colonoscopia. Métodos - Após as colonoscopias, distribuíram-se os indivíduos em dois grupos: pacientes com adenomas de cólon (casos) e pacientes com cólons normais (controles), pareados por idade e sexo. Em ambos os grupos, realizou-se dosagem sérica de IgG contra o Helicobacter pylori através de ensaio imunométrico quimioluminescente em fase sólida. Os dados foram analisados pelo teste do qui ao quadrado. Resultados - Foram 94 casos e 94 controles, 30 homens e 64 mulheres em cada grupo. A idade média dos casos e controles foi de 59,79 $\pm 12,25$ anos e 58,98 $\pm 11,55$ anos, respectivamente. A sorologia para Helicobacter pylori foi positiva em $66(70,21 \%)$ casos e em $51(54,25 \%)$ controles, diferença estatisticamente significativa $(P=0,024)$. O "odds ratio" foi de 1,98 (CI 95\%, 0,82 - 3,15). A prevalência de Helicobacter pylori em casos e controles de acordo com o sexo, tipo histológico e localização das lesões no cólon somente apresentou diferença significativa entre as mulheres $(P=0,03)$, pacientes com adenomas tubulares $(P=0,03)$ e naqueles com adenomas distais $(P=0,038)$. Conclusões - Há associação positiva entre a infecção pelo H. pylori e os adenomas colônicos. Esta relação é mais evidente em mulheres, em adenomas tubulares e de localização colônica distal.

DESCRITORES - Helicobacter pylori. Adenoma. Neoplasias do cólon. Infecções por Helicobacter.

\section{REFERENCES}

1. Aydin A, Karasu Z, Zeytinoglu A, Kumanlioglu K, Özacar T. Colorectal adenomateous polyps and Helicobacter pylori infection. Am J Gastroenterol. 1999;94:1121-2.

2. Breuer-Katschinski B, Nemes K, Marr A, Rump B, Leiendecker B, Breuer N, Goebell $\mathrm{H}$, and Colorectal Adenoma Study Group. Helicobacter pylori and the risk of colonic adenomas. Digestion 1999;60:210-5.

3. Bulajic M, Stimec B, Jesenofsky R, Kecmanovic D, Ceranic M, Kostic N, SchneiderBrachert W, Lowenfels A, Maisonneuve P, Lohr JM. Helicobacter pylori in colorectal carcinoma tissue. Cancer Epidemiol Biomarkers Prev. 2007;16:631-3.

4. Cordeiro FTM, Moraes Filho JPP, Magalhães AFN, Guarita DR, Dantas W, Kotze LMS, Habr-Gama A, Mattos AA, Alves JG. Condutas em gastroenterologia. São Paulo: Revinter; 2004.

5. Fireman Z, Trost L, Kopelman Y, Segal A, Sternberg A. Helicobacter pylori: seroprevalence and colorectal cancer. Isr Med Assoc J. 2000;2:6-9.

6. Fujimori S, Kishida T, Kobayashi T, Sekita Y, Tsuguhiko S, Nagata K, Tatsuguchi A, Gudis K, Yokoi K, Tanaka N, Yamashita K, Tajiri T, Ohaki Y, Sakamoto C. Helicobacter pylori infection increases the risk of colorectal adenoma and adenocarcinoma, especially in women. J Gastroenterol. 2005;40:887-93.

7. Georgopoulos SD, Polymeros D, Triantafyllou K, Spiliadi C, Mentis A, Karamanolis DG, Ladas SD. Hypergastrinemia is associated with increased risk of distal colon adenomas. Digestion. 2006;74:42-6.

8. Grahn N, Hmani-Aifa M, Fransén K, Söderkvist P, Monstein HJ. Molecular identification of Helicobacter DNA present in human colorectal adenocarcinomas by $16 \mathrm{~S}$ rDNA PCR amplification and pyrosequencing analysis. J Med Microbiol. 2005;54:1031-5

9. Hamilton SR, Aaltonen LA, editors.. Pathology and genetics of tumours of the digestive system. Lyon: IARC Press; 2000. (WHO classification of tumours 2).
10. Hartwich A, Konturek SJ, Pierzchalski P, Zuchowicz M, Labza H, Konturek PC, Karczewska E, Bielanski W, Marlicz K, Starzynska T, Lawniczak M, Hahn EG. Helicobacter pylori infection, gastrin, cyclooxygenase-2, and apoptosis in colorectal cancer. Int J Colorectal Dis. 2001;16:202-10.

11. Hartwich J, Konturek SJ, Pierzchalski P, Zuchowicz M, Konturek PC, Bielanski W, Marlicz K, Starzynska T, Lawniczak M. Molecular basis of colorectal cancer - role of gastrin and cyclooxygenase-2. Med Sci Monit 2001;7:1171-81.

12. Hatakeyama M, Brzozowski T. Pathogenesis of Helicobacter pylori infection. Helicobacter. 2006;11(Suppl 1):14-20.

13. Hocker M, Hohenberger P. Helicobacter pylori virulence factors - one part of a big picture. Lancet 2003;362:1231-3.

14. Israel DA, Peek RM. Pathogenesis of Helicobacter pylori-induced gastric inflammation. Aliment Pharmacol Ther. 2001:15:1271-90.

15. Jones M, Helliwell P, Pritchard C, Tharakan J, Mathew J. Helicobacter pylori in colorectal neoplasms: is there an aetiological relationship? World J Surgical Oncol. 2007:5:51-64

16. Kivi M, Tindberg Y, Sörberg M, Casswall TH, Hellström PM, Bengtsson C, Engstrand L, Grar M. Concordance of Helicobacter pylori strains within families. J Clin Microbiol. 2003;41:5604-8.

17. Konturek SJ, Konturek PC, Hartwich A, Hahn EG. Helicobacter pylori infection and gastrin and cyclooxygenase expression in gastric and colorectal malignancies. Regul Pept. 2000;93:13-9.

18. Limburg PJ, Stolzenberg-Solomon RZ, Colbert LH, Perez-Perez GI, Blaser MJ, Taylor PR, Virtamo J, Albanes D. Helicobacter pylori seropositivity and colorecatal cancer risk: a prospective study on male smokers. Cancer Epidemiol. 2002;11:1095-9.

19. Lyra AC, Santana G, Santana N, Silvany-Neto A, Magalhaes E, Pereira EM, Mascarenhas R, Lyra MC, Veiga A, Ferreira K, Zaterka S, Lyra LG. Seroprevalence and risk factors associated with Helicobacter pylori infection in blood donors in Salvador, Northeast-Brazil. Braz J Infect Dis. 2003;7:339-45. 
20. Malecka-Panas E, Fligiel SE, Jaszewski R, Majumdar AP. Differential responsiveness of proximal and distal colonic mucosa to gastrin. Peptides. 1997;18:559-65.

21. Marshall BJ, Warren, JR. Unidentified curved bacilli in the stomach of patients with gastritis and peptic ulceration. Lancet. 1984;2:1311-4.

22. Mégraud F. When and how does Helicobacter pylori infection occur? Gastroenterol Clin Biol. 2003;27:374-9.

23. Meucci G, Tatarella M, Vecchi M, Ranzi ML, Biguzzi E, Beccari G, Clerici E, De Franchis R. High prevalence of Helicobacter pylori infection in patients with colonic adenomas and carcinomas. J Clin Gastroenterol. 1997;24:605-7.

24. Mizuno S, Morita Y, Inui T, Asakawa A, Ueno N, Ando T, Kato H, Uchida M, Yoshikawa T, Inui A. Helicobacter pylori infection is associated with colon adenomatous polyps detected by high-resolution colonoscopy. Int J Cancer. 2005;117:1058-9.

25. Moss SF, Neugut AI, Garbowski GC, Wang S, Treat MR, Forde KA. Helicobacter pylori seroprevalence and colorectal neoplasia evidence against an association. J Natl Cancer Inst. 1995;87:762-3.

26. Nascimento RS, Valente SRG, Oliveira LCM. Seroprevalence of Helicobacter pylor infection in chronic chagasic patients, and in the rural and urban population from Uberlândia, Minas Gerais, Brazil. Rev Inst Med Trop S Paulo. 2002;44:251-4.

27. Oliveira AMR, Queiroz DMM, Rocha GA, Mendes EN. Seroprevalence of Helicobacter pylori infection in children of low socioeconomic level in Belo Horizonte, Brazil. Am J Gastroenterol. 1994;89:2201-4.

28. Rodosz-Komoniewska H, Bek T, Józwiak J, Martirosian G. Pathogenicity of Helicobacter pylori infection. Clin Microbiol Infect. 2005;11:602-10.

29. Rodrigues MN, Queiroz DMM, Rodrigues RT, Rocha AMC, Luz CRL, Braga LLBC. Prevalence of Helicobacter pylori infection in Fortaleza, Northeastern Brazil. Rev Saude Publica. 2005;39:847-9.

30. Shmuely H, Passaro D, Figer A, Niv Y, Pitlik S, Samra Z, Koren R, Yahav J. Relationship between Helicobacter pylori CagA status and colorectal cancer. Am J Gastroenterol. 2001;96:3406-10.
31. Siddheshwar RK, Muhammad KB, Gray JC, Kelly SB. Seroprevalence of Helicobacter pylori in patients with colorectal polyps and colorectal carcinoma. Am J Gastroenterol. 2001;96:84-8

32. Souto FJ, Fontes CJ, Rocha GA, de Oliveira AM, Mendes EN, Queiroz DM. Prevalence of Helicobacter pylori infection in a rural area of the state of Mato Grosso, Brazil. Mem Inst Oswaldo Cruz. 1998;93:171-4.

33. Takeda H, Asaka M. Helicobacter pylori and colorectal neoplasm: a mysterious link? J Gastroenterol. 2005;40:919-20

34. Thomas JE, Gibson GR, Darboe MK, Dale A, Weaver LT. Isolation of Helicobacter pylori from human faeces. Lancet. 1992;340:1194-5.

35. Thorburn CM, Friedman GD, Dickinson CJ, Vogelman JH, Orentreich N, Parsonne J. Gastrin and colorectal cancer: a prospective study. Gastroenterology. 1998;115: 275-80.

36. Van Der Ende A, Van Der Hulst RW, Roorda P, Tytgat GN, Dankest J. Evaluation of three comercial serological tests with different methodologies to asses Helicobacter pylori infection. J Clin Microbiol. 1999;37:4120-2.

37. Wagner S, Haruma K, Gladziwa U, Soudah B, Gebel M, Bleck J, Schimidt H, Manns M. Helicobacter pylori infection and pepsinogen $\mathrm{A}$, pepsinogen $\mathrm{C}$ and gastrin in gastritis and peptic ulcer: significance of inflammation and effect of bacterial eradication. Am J Gastroenterol. 1995;89:1211-8.

38. Yang L, Pei Z. Bacteria, inflammation, and colon cancer. World J Gastroenterol. 2006;12:6741-6.

39. Zaterka S, Eisig JN, Chinzon D, Rothstein W. Factors related to Helicobacter pylori prevalence in an adult population in Brazil. Helicobacter. 2007;12:82-8.

40. Zumkeller N, Brenner H, Zwahlen M, Rothenbacher D. Helicobacter pylori infection and colorectal cancer risk: a meta-analysis. Helicobacter. 2006;11:75-82.

Recebido em 10/3/2008. Aprovado em 3/7/2008. 